\title{
A Culturally Sensitive and Supportive Maternity Care Service Increases the Uptake of Maternity Waiting Homes in Ethiopia
}

This article was published in the following Dove Press journal: International Journal of Women's Health

\author{
Desta Workneh Selbana' \\ Msganaw Derese ${ }^{2}$ \\ Enatfenta Sewmehone Endalew' \\ Bosena Tebeje Gashaw (D) \\ 'College of Health Sciences, Jimma \\ University, Jimma, Ethiopia; ${ }^{2}$ College of \\ Health Sciences, Mizan-Tepi University, \\ Mizan-Tepi, Ethiopia
}

Background: Maternal delays in utilization of emergency obstetric care are impacting on a high maternal mortality, especially in the poor resource countries including Ethiopia. Different strategies are designed and employed to reduce those maternal delays, and one of such strategies employed to overcome the geographic barriers and improve maternal and neonatal health outcomes is utilization of maternity waiting homes (MWHs). Studies related to the utilization of MWHs and associated factors are limited in Ethiopia and there were none in the study area.

Objective: The aim of this study was to assess the utilization of maternity waiting homes and associated factors.

Methods and Materials: A community-based cross-sectional study design was conducted, using multistage sampling technique. Logistic regression analysis with $95 \%$ CI for odds ratio (OR) was used to identify significant factors.

Results: A total of 379 women participated in this study, making a response rate of $85 \%$. Of the total participants, $42.5 \%(95 \% \mathrm{CI}=38-48)$ of women utilized MWHs. After controlling for potential confounders, women's decision-making capacity ( $\mathrm{AOR}=12.74 ; 95 \% \mathrm{CI}=6.18$ 26.26), women having someone who can care for their children and/or husband at home ( $\mathrm{AOR}=2.71$; 95\% CI=1.44-5.09), MWHs offering food service $(\mathrm{AOR}=4.03$; 95\% $\mathrm{CI}=2.07-$ 7.85 ), offering and/or allowing women to practice their own cultural ceremony (allowing to cook their own food type, porridge, coffee, etc) (AOR=9.55;95\% CI=4.45-20.47), and women's attitude towards MWHs ( $\mathrm{AOR}=0.09 ; 95 \% \mathrm{CI}=0.03-0.23)$ were factors significantly associated with the utilization of MWHs.

Conclusion: Compared to its contribution in reducing maternal and perinatal mortality, the utilization of MWHs was low in this study area. The integration of culturally sensitive and supportive maternity services, along with community participatory approach, would increase utilization of MWHs and consequently contribute in achieving the SDGs related to maternal and neonatal health.

Keywords: maternity waiting homes, utilization, supportive maternity services, cultural sensitivity, Ethiopia

\section{Introduction}

The WHO reported more than 300,000 women died from pregnancy-related causes annually and 830 died each day worldwide, ${ }^{1-3}$ with the greatest burden (99\%) of maternal mortality falling on the low and middle income countries (LMICs), and more millions suffer obstetric morbidities. ${ }^{4,5}$ These adversities of pregnancy outcomes would partly be defeated by addressing maternity waiting homes (MWHs). ${ }^{6}$
Correspondence: Desta Workneh Selbana

College of Health Sciences, Jimma University, PO Box, 378, Jimma, Ethiopia Email destaw1977@gmail.com
International Journal of Women's Health 2020:| 2 8|3-82 I 
MWHs are temporary shelters for pregnant women, and located near a qualified medical facility, where women identified as "high risk" can await their delivery and be transferred to a nearby medical facility shortly before delivery, or earlier should any complications arise, ${ }^{7}$ for interventions including cesarian sections and blood transfusion.

Ethiopia introduced a three-tiered healthcare system that includes primary healthcare units (PHCUs) (consisting of primary/district hospitals, health centers, and community-based health posts); general hospitals (level 2), and specialized hospitals (level 3). ${ }^{8}$ According to the national guidelines of Ethiopia, women who live far away from health centers, are not accessible by ambulance, are term pregnancy (38 or more weeks of gestation), and/or are at risk of experiencing obstetrical complications during pregnancy and/or delivery are eligible for MWH referrals. ${ }^{9}$

Studies reported MWHs have significant importance in reducing maternal and perinatal mortalities. ${ }^{10}$ The WHO has endorsed MWHs since the 1950s as one component of a comprehensive package to reduce maternal morbidity and mortality, ${ }^{11}$ primarily to be used in the LMICs to bridge the geographic barriers for women living far from health facilities, ${ }^{7,12}$ considerably overcoming the three delays contributing to maternal mortality. ${ }^{13,14}$

Ethiopia has implemented MWHs since $1976,{ }^{7}$ as more than $80 \%$ of people live rurally with limited access to skilled obstetric care, still experiencing high maternal and neonatal mortality, ${ }^{15}$ while only $28 \%$ of women delivered by skilled health professionals, ${ }^{16}$ entailing the need for addressing MWHs, among others. In 2015, the Ethiopian Ministry of Health (MOH) revised the MWHs' guidelines which transform the historical justification of MWHs from targeting only "high risk pregnant" women to "consider all pregnancy as high risk", and bring all women around term pregnancy to MWHs; leading to increased skill birth attendances (SBAs), ${ }^{9}$ and institutional delivery over the last 6 years. ${ }^{17}$ While MWHs facilitate emergency obstetric care (EmOC), they are also part of the strategies utilized to improve access for the hard to reach rural populations and increasing the proportion of skilled birth care. $^{18}$

Achieving the target of increasing the proportion of skilled birth attendants (SBAs) requires addressing the socio-cultural, distance, and financial barriers prohibiting mothers from utilizing health facilities. ${ }^{19,20}$ Evidence has also noted that the effectiveness of MWHs is affected by its quality, including leaving childcare at home and the cultural costs of being away from the home for childbirth. ${ }^{21-23}$ However, studies on this area are limited in Ethiopia and certainly non-existent in the study setting. Therefore, this study tries to look into the utilization of MWHs and its associated factors (see Figure 1), in an effort to enlighten evidence-informed interventions and policy leading to an increased level of institutional births, and timely identification and management of complications during pregnancy and childbirth, ultimately reducing maternal and neonatal death.

\section{Methods and Materials \\ Study Setting}

The study was conducted from March 26, 2018-April 11, 2018, in Gimbo district, Keffa Zone. This district is one of the 11 districts found in Keffa zone. Gimbo town is the capital of Gimbo district, and is 452 and $18 \mathrm{~km}$ from Addis Ababa and Bonga town, respectively. There are six health centers and 32 health posts, and all health centers have maternity waiting homes. According to the 2017 data, the district has a total population of 118,059 , and 32 rural Kebeles (the lowest administrative units). From these Kebeles there were 1643 mothers who gave birth in the last year.

\section{Study Design, Participants, and Sampling}

Using a community-based cross-sectional study design and multistage sampling technique, all mothers (from all 32 Kebeles) who gave birth in the last year in the district were considered as a source population, and mothers resided from ten randomly selected Kebeles (the lowest administrative unit) as a study population. The participants' sample size was computed by using a single population proportion formula: considering the prevalence of utilization of MWHs was $38.7 \%(P=0.387)$ in a previous study conducted in Ethiopia, ${ }^{24}$ standard normal distribution of the $\mathrm{Z}$-value at $95 \%$ confidence interval $(\mathrm{CI})=1.96$, and $5 \%$ margin of error, become 365 , and since the source population is less than 10,000 , we used a correction formula which reduced the sample to 298 , and a 1.5 design effect (considering multistage sampling) made the final sample size 447 . The calculated sample size was proportionally allocated to the selected 10 Kebeles. Then eligible participants were selected randomly from these Kebeles. 


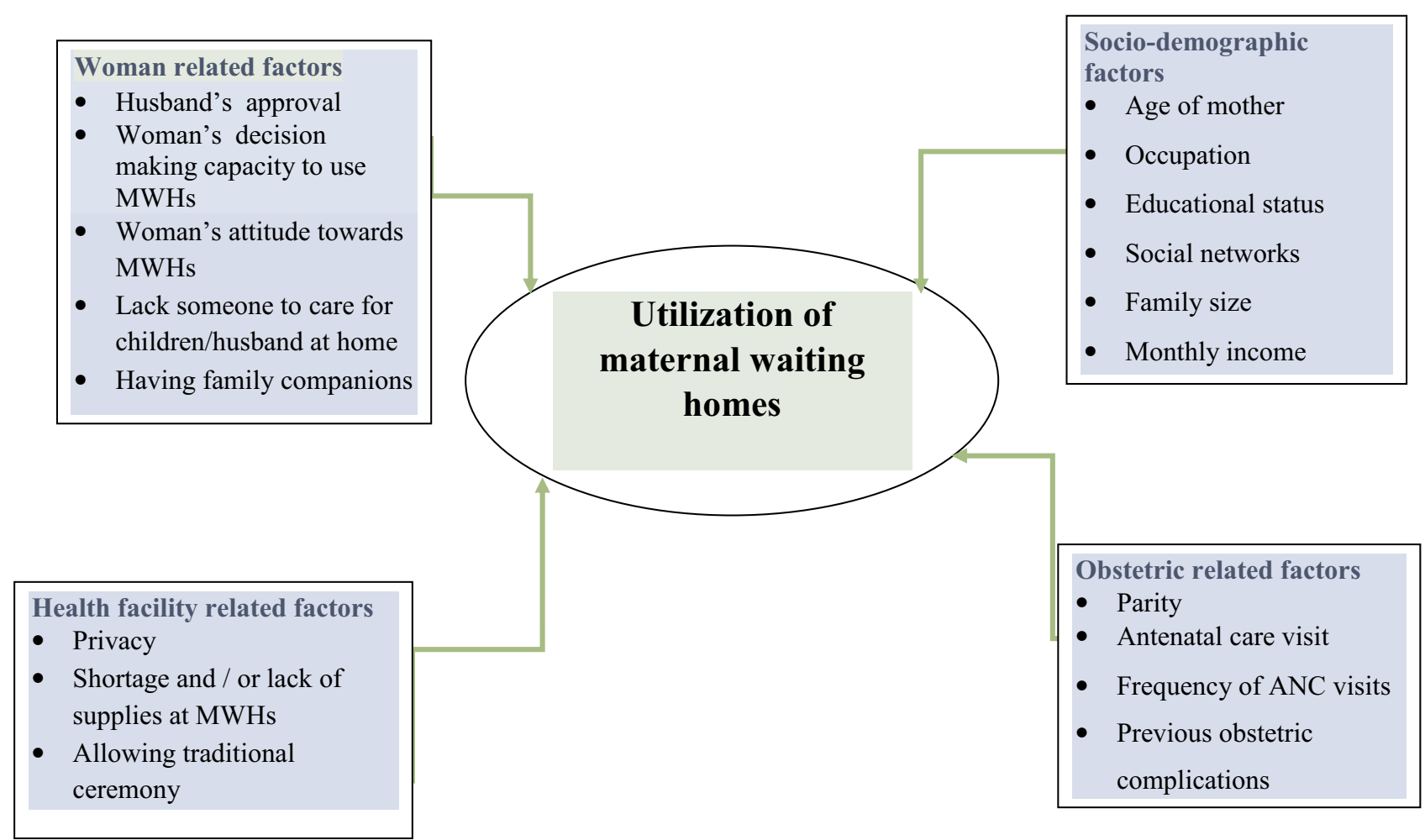

Figure I Conceptual framework illustrating factors associated with utilization of maternal waiting homes.

\section{Instrument and Data Collection Procedures}

Utilization of MWHs is the outcome variable, while sociodemographic, health-facility, obstetric, and maternalrelated factors, as illustrated in Figure 1, are the exposure variables in this study. A pretested questionnaire adapted from previous relevant literatures were administered using a face-to-face interview. The questionnaire was prepared in English and then translated to Amharic and to local language (Kafinoonoo), then back translated to English by a language expert. Seven trained clinical nurses, with the assistance of the respective Kebele leaders in accessing eligible participants (those women who gave birth in the last year and resident in the selected kebeles), conducted house-to-house interviews with women at their homes privately. The interviews took an hour on average. Two supervisors having BSc midwifery backgrounds supervised data collection.

\section{Data Entry and Analysis}

Data collected was coded and entered into Epi-Data 3.1 statistical software, then exported and analyzed using SPSS version 23.0 statistical software. Descriptive analyses were carried out for each of the variables. Variables having $P$-values less or equal to 0.25 were considered candidates and entered into the multivariate logistic regression model to identify the independent effects of each variable on the outcome. Finally, variables with a $P$-value of less than 0.05 with a $95 \% \mathrm{CI}$ for odds ratio (OR) were considered to have a significant association between exposure and outcome variables.

\section{Ethical Approval and Consent to Participate}

Ethical approval was obtained from Jimma University College of Health sciences (CHSs) Institutional Review Board (IRB), and submitted to Keffa Zone health department to get permission. Then a collaboration letter was obtained from Keffa Zone health bureau and submitted to the district health departments followed by to each selected Kebele. Verbal and written consent for data collection was obtained from eligible participants. For participants under the age of 18 years, no parental informed consent was required according to the Ethiopia National Research Ethics Review Guideline (2014) section 8.3.5.3, as emancipated minors (ie, those working or earns their living, married, parenting may be allowed to give an 
informed consent or an IRB may decide a waiver of consent. Trained research assistants read out the contents of the consent forms outlining the study objectives and investigators involved and describing what was expected from women as well as associated risks and benefits. This was done in a local language of women's preferences (Amharic or Kafinoonoo). Prior to enrolment, participants were told that their name would not be mentioned, their rights as participants, and their questions were answered.

\section{Results}

\section{Characteristics of Participants}

A total of 447 mothers were interviewed, and 379 gave complete responses, making a response rate of $85 \%$. The mean age of the respondents was $27(\mathrm{SD}= \pm 5.1)$ years. Most of the respondents 299 (78.9\%) were home-makers, $309(81.5 \%)$ respondent's husbands were farmers, and 190 $(50.1 \%)$ had no education. Two hundred and one $(53.3 \%)$ were orthodox Christian, followed by protestant (82, $21.6 \%), 279(73.6 \%)$ belong to Keffa ethnic group and $246(64.9 \%)$ earned a monthly income ranging from 5011499 ETB (Table 1).

\section{Maternal-Related Factors}

From the total 379 respondents, $42.5 \%$ of them utilized the MWHs service, 195 (51.5\%) faced husband refusal to go and stay at MWHs, 211 (55.7\%) had no one to care for their children/husband while at MWHs, 222 (58.6\%) of mothers had no concern about their marriage while staying at MWHs, and 253 (58.8\%) of women had no companion to MWHs (Table 2). While 178 (47\%) of the participants reported the decision of whether to go and stay to MWHs or not was made by their husbands.

\section{Health Facility-Related Factors}

The mean duration of stay at MWHs was 16 days. Regarding resources at MWHs, $62 \%$ of women reported the absence of privacy, $64.6 \%$ comfort, $41.2 \%$ food service, $84.2 \%$ blankets, bed mattress and extra space for sleeping, $19 \%$ electric power, $37.2 \%$ extra space for cooking food, coffee ... etc, $34.8 \%$ toilets, $72.8 \%$ bath room, $82.6 \%$ water supply and firewood, $81.0 \%$ traditional ceremony after delivery, and $65.2 \%$ reported that rooms were too small and crowded (Table 2), and 20.1\% had negative attitudes towards utilization of maternal waiting homes.
Table I Socio-Demographic Characteristics of the Respondents $(\mathrm{N}=379)$

\begin{tabular}{|c|c|c|c|}
\hline Variables & Category & Frequency & Percent (\%) \\
\hline Age & $\begin{array}{l}15-19 \\
20-24 \\
25-29 \\
30-34 \\
35 \text { and above }\end{array}$ & $\begin{array}{l}32 \\
99 \\
134 \\
72 \\
42\end{array}$ & $\begin{array}{l}8.4 \\
26.1 \\
35.4 \\
19.0 \\
11.1\end{array}$ \\
\hline $\begin{array}{l}\text { Maternal } \\
\text { occupation }\end{array}$ & $\begin{array}{l}\text { Housewife } \\
\text { Farmer } \\
\text { Student } \\
\text { Merchant } \\
\text { Governmental/ } \\
\text { NGO employment }\end{array}$ & $\begin{array}{l}299 \\
54 \\
12 \\
7 \\
7\end{array}$ & $\begin{array}{l}78.9 \\
14.2 \\
3.2 \\
1.8 \\
1.8\end{array}$ \\
\hline $\begin{array}{l}\text { Husbands } \\
\text { occupation }\end{array}$ & $\begin{array}{l}\text { Farmer } \\
\text { Merchant } \\
\text { Daily laborer } \\
\text { Governmental } \\
\text { employee }\end{array}$ & $\begin{array}{l}309 \\
44 \\
13 \\
13\end{array}$ & $\begin{array}{l}81.5 \\
11.6 \\
3.4 \\
3.4\end{array}$ \\
\hline $\begin{array}{l}\text { Maternal } \\
\text { educational } \\
\text { level }\end{array}$ & $\begin{array}{l}\text { No education } \\
\text { Primary }(1-8) \\
\text { Secondary }(9-10) \\
\text { Preparatory and } \\
\text { above }\end{array}$ & $\begin{array}{l}190 \\
169 \\
12 \\
8\end{array}$ & $\begin{array}{l}50.1 \\
44.6 \\
3.2 \\
2.1\end{array}$ \\
\hline $\begin{array}{l}\text { Husbands } \\
\text { educational } \\
\text { level }\end{array}$ & $\begin{array}{l}\text { No education } \\
\text { Primary }(I-8) \\
\text { Secondary }(9-10) \\
\text { Preparatory and } \\
\text { above }\end{array}$ & $\begin{array}{l}152 \\
194 \\
20 \\
13\end{array}$ & $\begin{array}{l}40.1 \\
51.2 \\
5.3 \\
3.4\end{array}$ \\
\hline Religion & $\begin{array}{l}\text { Muslim } \\
\text { Orthodox } \\
\text { Protestant } \\
\text { Catholic }\end{array}$ & $\begin{array}{l}75 \\
201 \\
82 \\
21\end{array}$ & $\begin{array}{l}19.8 \\
53.0 \\
21.6 \\
5.5\end{array}$ \\
\hline Ethnicity & $\begin{array}{l}\text { Keffa } \\
\text { Amhara } \\
\text { Oromo }\end{array}$ & $\begin{array}{l}279 \\
67 \\
33\end{array}$ & $\begin{array}{l}73.6 \\
17.7 \\
8.7\end{array}$ \\
\hline $\begin{array}{l}\text { Average } \\
\text { monthly } \\
\text { income }\end{array}$ & $\begin{array}{l}\leq 500 \text { ETB } \\
501-1499 \\
1500-2499 \\
2500-3499 \\
3500 \text { and above }\end{array}$ & $\begin{array}{l}86 \\
246 \\
35 \\
9 \\
3\end{array}$ & $\begin{array}{l}22.7 \\
64.9 \\
9.2 \\
2.4 \\
0.8\end{array}$ \\
\hline Family size & $\begin{array}{l}\text { I-5 } \\
5-7 \\
\text { above } 7\end{array}$ & $\begin{array}{l}263 \\
92 \\
24\end{array}$ & $\begin{array}{l}69.4 \\
24.3 \\
6.3\end{array}$ \\
\hline
\end{tabular}

Factors Associated with the Utilization of MWH Services

Multivariable logistic regression analysis adjusted for potential confounders show mothers who can make the 
Table 2 Maternal and Health Facility-Related Factors $(\mathrm{N}=379)$

\begin{tabular}{|c|c|c|c|}
\hline Maternal-Related Factors & Category & Frequency & $\%$ \\
\hline \multirow{2}{*}{$\begin{array}{l}\text { Having someone to care for } \\
\text { their children/husbands }\end{array}$} & Yes & 168 & 44.3 \\
\hline & No & 211 & 55.7 \\
\hline \multirow{2}{*}{$\begin{array}{l}\text { Husband's approval of woman's } \\
\text { going and staying at MWHs }\end{array}$} & Yes & 195 & 51.5 \\
\hline & No & 184 & 48.5 \\
\hline \multirow{2}{*}{$\begin{array}{l}\text { Concern about their marriage } \\
\text { when they stay in } \mathrm{MWH}\end{array}$} & Yes & 157 & 41.4 \\
\hline & No & 222 & 58.6 \\
\hline \multirow{2}{*}{$\begin{array}{l}\text { Having family member to } \\
\text { accompany and stay in the } \mathrm{MWH}\end{array}$} & Yes & 156 & 41.2 \\
\hline & No & 223 & 58.8 \\
\hline \multicolumn{4}{|c|}{ Health Facility Service-Related Factors } \\
\hline \multirow[t]{2}{*}{ Privacy in MWHs \& labour ward } & Yes & 144 & 38.0 \\
\hline & No & 235 & 62.0 \\
\hline \multirow[t]{2}{*}{ Having companion at $\mathrm{MWHs}$} & Yes & 134 & 35.4 \\
\hline & No & 245 & 64.6 \\
\hline \multirow[t]{2}{*}{ Availability of food service } & Yes & 220 & 58.0 \\
\hline & No & 159 & 42.0 \\
\hline \multirow{2}{*}{$\begin{array}{l}\text { Availability of blankets, bed } \\
\text { mattress, and other materials }\end{array}$} & Yes & 60 & 15.8 \\
\hline & No & 319 & 84.2 \\
\hline \multirow{2}{*}{$\begin{array}{l}\text { Regular visit of the mother by } \\
\text { midwives }\end{array}$} & Yes & 258 & 68.1 \\
\hline & No & 121 & 31.9 \\
\hline \multirow[t]{2}{*}{ Accessibility of electric power } & Yes & 307 & 81.0 \\
\hline & No & 72 & 19.0 \\
\hline \multirow{2}{*}{$\begin{array}{l}\text { Maternity waiting home too } \\
\text { small or crowded }\end{array}$} & Yes & 247 & 65.2 \\
\hline & No & 132 & 34.8 \\
\hline \multirow{2}{*}{$\begin{array}{l}\text { Availability of extra space for } \\
\text { cooking food, coffee, etc. }\end{array}$} & Yes & 238 & 62.8 \\
\hline & No & 141 & 37.2 \\
\hline \multirow[t]{2}{*}{ Availability of toilets } & Yes & 247 & 65.2 \\
\hline & No & 132 & 34.8 \\
\hline \multirow[t]{2}{*}{ Availability of bath rooms } & Yes & 103 & 27.2 \\
\hline & No & 276 & 72.8 \\
\hline \multirow{2}{*}{$\begin{array}{l}\text { Availability of water supply and } \\
\text { firewood }\end{array}$} & Yes & 66 & 17.4 \\
\hline & No & 313 & 82.6 \\
\hline \multirow{2}{*}{$\begin{array}{l}\text { Availability of traditional } \\
\text { ceremony after delivery }\end{array}$} & Yes & 72 & 19.0 \\
\hline & No & 307 & 81.0 \\
\hline
\end{tabular}

decision by themselves to utilize MWHs were nearly 13times (AOR $=12.74 ; 95 \% \mathrm{CI}=6.18-26.26$ ), those who had someone to care for their children/husbands at home nearly 3-times $(\mathrm{AOR}=2.71 ; 95 \% \mathrm{CI}=1.44-5.09)$, those who got meal service at $\mathrm{MWHs} 4$-times $(\mathrm{AOR}=4.03$; 95\% CI $=2.07-7.85)$ and those who are offered extra space for cooking food, coffee, etc, nearly 10-times ( $\mathrm{AOR}=9.55 ; 95 \% \mathrm{CI}=4.45-20.47$ ] more likely to use
MWHs than their counterparts. Mothers who had negative attitude towards the utilization of MWHs were $91 \%$ times (AOR $=0.09 ; 95 \% \mathrm{CI}=0.03-0.23$ )] less likely to utilize MWHs than mothers who had a positive attitude (Table 3).

\section{Discussion}

Our study identified low utilization of MWHs was linked with socio-economic, demographic, cultural, and facilityrelated constraints. Only $42.5 \%$ of women in our study utilized MWHs, which is higher than previous studies done in Ethiopia, ${ }^{24,25}$ and Zambia (27.3\%). ${ }^{26}$ The availability of MWHs in all health centers in the study area, the recent health policy of the government of Ethiopia targeting to decrease the maternal and child mortality, the presence of health extension workers (HEWs) who can reach out to the grass-root level community and linking their service to the next level health institutions in Ethiopia are possible explanations accounting for the use of MWHs being higher than those reported in the previous studies mentioned above. However, this result is lower than the studies done in Kenya (61\%), ${ }^{27}$ and Zimbabwe (59.2\%). ${ }^{28}$ However, the disparity between these studies reporting a higher rate of utilization might be due to the difference in the quality of services and social backgrounds, ${ }^{27}$ and can be considered as an alarm for Ethiopia to improve the quality of services at the MWHs.

The Ethiopian government made various efforts towards making safe-motherhood a priority. Launching a number of midwifery training programs, ${ }^{29}$ health extension programs (HEP), ${ }^{8}$ and scaling-up MWHs, ${ }^{9}$ which were initially concentrated at the hospital level but have more recently been implemented at health centers, are some of the initiatives illustrating these efforts. Proper implementation of MWHs at the health centre level improved access to the basic emergency obstetric and newborn care (BEmONC), ${ }^{30,31}$ which constitutes the seven signal functions: administering parenteral antibiotics, oxytocic drugs, and anticonvulsants; manual removal of the placenta and retained products; and perform assisted vaginal birth and, basic neonatal resuscitation. ${ }^{32}$ Women in severe complications and laboring women requiring referral to the nearest comprehensive emergency obstetric and newborn care (CEmONC) facility will be referred to a facility that can perform two additional functions, cesarean section and blood transfusion. ${ }^{32}$ This, in turn, demonstrates establishing functional MWHs considerably contribute to prevent maternal and perinatal mortality. ${ }^{10,30,33}$ Likewise, systematically reviewed studies in Ethiopia 
Table 3 Multivariate Logistic Regression Analysis of Factors Associated with Utilization of MWHs (N=379)

\begin{tabular}{|c|c|c|c|c|c|c|}
\hline \multirow[t]{2}{*}{ Variables } & \multirow[t]{2}{*}{ Category } & \multicolumn{2}{|c|}{ MWH Utilization } & \multirow[t]{2}{*}{ COR $(95 \% \mathrm{Cl})$} & \multirow[t]{2}{*}{ AOR $\left(95 \% \mathrm{Cl}_{-}\right.$} & \multirow{2}{*}{$\begin{array}{l}P \text { - } \\
\text { value }\end{array}$} \\
\hline & & Utilized & $\begin{array}{l}\text { Not } \\
\text { Utilized }\end{array}$ & & & \\
\hline Decision-maker for the utilization of MWHs & $\begin{array}{l}\text { My self } \\
\text { My family } \\
\text { Husbands }\end{array}$ & $\begin{array}{l}119 \\
8 \\
34\end{array}$ & $\begin{array}{l}59 \\
17 \\
142\end{array}$ & $\begin{array}{l}8.42(5.17-13.7) \\
1.965(0.78-4.93) \\
1\end{array}$ & $\begin{array}{l}12.74(6.18-26.26) \\
2.68(0.81-8.86) \\
\text { I }\end{array}$ & $\begin{array}{l}<0.001 \\
0.105\end{array}$ \\
\hline $\begin{array}{l}\text { Having someone for child and/or husband } \\
\text { care }\end{array}$ & $\begin{array}{l}\text { Yes } \\
\text { No }\end{array}$ & $\begin{array}{l}103 \\
58\end{array}$ & $\begin{array}{l}69 \\
149\end{array}$ & $\begin{array}{l}3.83(2.49-5.89) \\
\text { I }\end{array}$ & $\begin{array}{l}2.71(1.44-5.09) \\
I\end{array}$ & $<0.01$ \\
\hline Availability of food service in $\mathrm{MWHs}$ & $\begin{array}{l}\text { Yes } \\
\text { No }\end{array}$ & $\begin{array}{l}122 \\
39\end{array}$ & $\begin{array}{l}98 \\
120\end{array}$ & $\begin{array}{l}3.83(2.44-5.99) \\
I\end{array}$ & $\begin{array}{l}4.03(2.07-7.85) \\
\text { I }\end{array}$ & $<0.001$ \\
\hline $\begin{array}{l}\text { Availability of extra space for cooking food, } \\
\text { coffee, etc }\end{array}$ & $\begin{array}{l}\text { Yes } \\
\text { No }\end{array}$ & $\begin{array}{l}140 \\
21\end{array}$ & $\begin{array}{l}98 \\
120\end{array}$ & $\begin{array}{l}8.16(4.8-13.87) \\
1\end{array}$ & $\begin{array}{l}9.55(4.45-20.47) \\
\text { I }\end{array}$ & $<0.001$ \\
\hline Husband approval to use $\mathrm{MWHs}$ & $\begin{array}{l}\text { Yes } \\
\text { No }\end{array}$ & $\begin{array}{l}38 \\
123\end{array}$ & $\begin{array}{l}157 \\
61\end{array}$ & $\begin{array}{l}0.12(0.075-0.195) \\
I\end{array}$ & $\begin{array}{l}0.17(0.09-0.32) \\
\mathrm{I}\end{array}$ & $<0.001$ \\
\hline Mother's attitude & $\begin{array}{l}\text { Negative } \\
\text { Positive }\end{array}$ & $\begin{array}{l}7 \\
154\end{array}$ & $\begin{array}{l}69 \\
149\end{array}$ & $\begin{array}{l}0.09(0.04-0.22) \\
\mathrm{I}\end{array}$ & $\begin{array}{l}0.09(0.031-0.23) \\
I\end{array}$ & $<0.001$ \\
\hline
\end{tabular}

Notes: I - reference group, and the above variables are adjusted for husband's educational level, whether woman had ANC follow-up during the index pregnancy, had previous obstetric complications, had a family companion to MWHs, had concern on her marriage while staying in MWHs, MWH was too small and/or crowded, has water supply and firewood.

showed MWHs contributed to an $83 \%$ reduction in stillbirths and a $91 \%$ reduction in maternal deaths compared to women who did not attend MWHs. ${ }^{6,10}$ This also illustrates the contribution of MWHs in achieving related SDGs, ${ }^{34,35}$ in the poor countries like Ethiopia.

Similar with the results of previous studies done in Ethiopia, ${ }^{24,36}$ and Mozambique, ${ }^{37}$ the odds of utilizing MWHs increases when mothers are in a position to make their own decision towards using MWHs in our study. We also identified that women who had someone to care for their children/husbands at home when they go and stay at MWHs were more likely to utilize MWHs than those who do not have such assistances, and this is in concordance with an earlier study done in Ethiopia. ${ }^{36}$ This again illustrates that, in Ethiopia, the burden of rearing children, taking care of household chores, and preparing food for the family are left to women, influencing their health, and signaling the need for male involvement in sharing household responsibilities including caring for children. On the other hand, MWHs allowing and arranging for pregnant women to bring their little kid/s with them would partly reduce such difficulty.

The utilization of MWHs and its facilities vary considerably across countries. Women bear different barriers when they want to go and stay at MWHs, including: poor MWH facilities, services, and sanitation issues; direct and indirect costs; lack of transportation; and being away from home and their children. ${ }^{11}$ In line with this, offering a meal service in MWHs increases the likelihood of utilizing MWHs in our study. The lack of services such as food insecurity at MWHs, cooking utensils, etc as potential barriers to utilize MWH were also identified by previous studies done in Ethiopia, ${ }^{38,39}$ Zambia ${ }^{26}$ Liberia, ${ }^{13}$ and other low resource countries in Africa. ${ }^{11}$ In this study mothers who admitted to the MWHs and provided extra space for cooking their own traditional food and coffee were positively and significantly associated with the use of MWHs, and this is consistent with the previous studies done in Ethiopia, ${ }^{36,38,40}$ Zimbabwe, ${ }^{11}$ and Zambia. ${ }^{22,26}$ Other studies also noted the absence of cooking utensils, the attendant being away from work, ${ }^{41}$ poor toilets and kitchens, a lack of space for family and companions, ${ }^{14}$ and provision of culturally inappropriate care as barriers to use MWHs. $^{23,42}$

Women may also face psycho-social and cultural costs of childbirth experiences when away from their home and community. Like other traditional societies, Ethiopian women highly value their tradition and culture (their food, dressing, coffee ceremony, prayers, etc), which may potentially influence their utilization of MWHs. This again demonstrates addressing a respectful and culturally appropriate service given by the health institutions increases utilization of MWHs. ${ }^{40,43}$ Provision of care, not in-line with the tradition 
of women discouraging the acceptability of MWHs, is also reported by another recent study that stated the care at MWHs that undermine women's culture and tradition in the low- and middle-income countries deterred women's ability to use them. ${ }^{14,42}$

Women's attitude towards MWHs is also an important component of its use. Consistent with previous studies done in Ethiopia, ${ }^{36,44}$ and Zambia, ${ }^{26}$ our study found when women having a negative attitude towards MWHs reduced its utilization by $91 \%$. On the other hand, healthcare workers attitude towards women using MWHs can also be equally detrimental, as a study in Kenya reported women at MWHs were not happy with healthcare workers' attitudes and proposed that staff should check on them regularly during their stay at the MWHs. ${ }^{45}$ Such negative attitudes from both sides need to be reversed by emphasizing the importance of using MWHs, embedding a caring, respectful, and compassionate (CRC) attitude among staff members and increasing basic social services for women while staying in the MWHs.

\section{Conclusion}

Utilization of MWHs in the study area was low (42.5\%), compared to studies done in some other African countries. Such a low utilization of MWHs is linked with socioeconomic, demographic, cultural, and facility-related constraints, and could consequently result in high maternal and neonatal mortality. As such women who can make decision by themselves to utilize MWHs, had someone to care for their children/husbands at home, were given a meal service at MWHs, allowed and/or offered extra space for cooking their own traditional food, coffee, etc, are more likely to use MWHs, as identified by our study. However, women who had a negative attitude towards the utilization of MWHs were less likely to use it. Therefore, respectful, culturally-appropriate, and supportive care at MWHs are recommended to improve its utilization and contribute to achieving the SDGs, particularly SDG 3.1 and 3.2), ${ }^{34,35}$ in the LMICs such as Ethiopia. It is also worth considering appropriate interventions, in emergency conditions, such as Covid-19 would disrupt the use of MWHs by promoting "the staying-at-home lockdowns".

\section{Strength and Limitation of the Study}

The tools prepared after reviewing relevant literatures, the reliability (internal consistency) of the tools checked using the Cronbach's alpha, (all $\geq 0.875$ ), using pre-tested primary data, multistage sampling and community based design, training, and supervision of data collectors may have enhanced the strength of this study. However, participants may not have provided their actual practice of MWHs, and consequently might have introduced social desirability bias and over-reporting. Furthermore, as this study is a cross-sectional design, we can neither infer a causal or temporal ordering of the associations. Thus, a large scale longitudinal study will help to produce better precisions and inform interventions and policy.

\section{Abbreviations}

$\mathrm{C} / \mathrm{S}$, cesarean section; $\mathrm{CI}$, confidence interval; FANC, focused antenatal care; CHSs, College of Health Sciences; FMOH, Federal Ministry of Health; H/C, health center; HEWs, health extension workers; IRB, Institutional Review Board; LMICs, low and middle income countries; MWHs, maternity waiting homes; SPSS, Statistical Package for the Social Sciences; WHO, World Health Organization.

\section{Data Sharing Statement}

All the data analyzed in this article are available from the corresponding author and can be obtained upon reasonable request.

\section{Acknowledgments}

We would like to acknowledge Jimma University for giving us the opportunity to do this research. We also acknowledge Keffa zonal health department, Gimbo district health office, supervisors, data collectors, and participants for their collaboration in this study.

\section{Author Contributions}

All authors made a significant contribution to the work reported, whether that is in the conception, study design, execution, acquisition of data, analysis and interpretation, or in all these areas; took part in drafting, revising, or critically reviewing the article; gave final approval of the version to be published; have agreed on the journal to which the article has been submitted; and agree to be accountable for all aspects of the work.

\section{Funding}

This study was funded by Jimma University, Ethiopia, who had no role in the design, data collection, analysis, and interpretation of the study. 


\section{Disclosure}

The authors declare that they have no conflicts of interest in this work.

\section{References}

1. Shakibazadeh E, Namadian M, Bohren MA, et al. Respectful care during childbirth in health facilities globally: a qualitative evidence synthesis. BJOG. 2018;125(8):932-942. doi:10.1111/1471-0528.15 015

2. Roser M, Ritchie H. Maternal mortality. Our World in Data. $2013 ; 245$.

3. Gulema H, Berhane Y. Timing of first antenatal care visit and its associated factors among pregnant women attending public health facilities in Addis Ababa, Ethiopia. Ethiop J Health Sci. 2017;27 (2):139-146. doi:10.4314/ejhs.v27i2.6

4. Nour NM. An introduction to maternal mortality. Rev Obstet Gynecol. 2008;1(2):77.

5. Mavalankar DV, Rosenfield A. Maternal mortality in resource-poor settings: policy barriers to care. Am J Public Health. 2005;95(2):200203. doi:10.2105/AJPH.2003.036715

6. Dadi TL, Bekele BB, Kasaye HK, Nigussie T. Role of maternity waiting homes in the reduction of maternal death and stillbirth in developing countries and its contribution for maternal death reduction in Ethiopia: a systematic review and meta-analysis. BMC Health Serv Res. 2018;18(1):748. doi:10.1186/s12913-018-3559-y

7. Organization WH. Maternity Waiting Homes: A Review of Experiences. World Health Organization; 1996.

8. Berhan Y, Berhan A. Commentary: actions in the pipeline and the way forward to reduce maternal and perinatal mortality in Ethiopia. Ethiop J Health Sci. 2014;24:149-168. doi:10.4314/ejhs.v24i0.13S

9. Ethiopia MoH. Guideline for the Establishment of Standardized Maternity Waiting Homes at Health Centers/Facilities. Author Addis Ababa; 2015.

10. Bekele BB, Umubyeyi A. Maternity waiting homes and skilled delivery in Ethiopia: review of strategy and implementation to drive sustainable development goals. Med Pract Rev. 2018;9(3):19-26. doi:10.5897/MPR2018.0137

11. van Lonkhuijzen L, Stekelenburg J, van Roosmalen J. Maternity waiting facilities for improving maternal and neonatal outcome in low-resource countries. Cochrane Database Sys Rev. 2012;10.

12. Figa'-Talamanca I. Maternal mortality and the problem of accessibility to obstetric care; the strategy of maternity waiting homes. Soc Sci Med. 1996;42(10):1381-1390. doi:10.1016/0277-9536(95)00286-3

13. Lori JR, Wadsworth AC, Munro ML, Rominski S. Promoting access: the use of maternity waiting homes to achieve safe motherhood. Midwifery. 2013;29(10):1095-1102. doi:10.1016/j.midw.2013.07.020

14. Penn-Kekana L, Pereira S, Hussein J, et al. Understanding the implementation of maternity waiting homes in low-and middle-income countries: a qualitative thematic synthesis. BMC Pregnancy Childbirth. 2017;17(1):269. doi:10.1186/s12884-017-1444-z

15. Berhan Y, Berhan A. Review of Maternal Mortality in Ethiopia: A story of the past 30 years. Ethiop J Health Sci. 2014;24:3-14.

16. Health FDRoEMo. HSTP Health Sector Transformation Plan 2015/ 16-2019/20 (2008-2012 EFY). Federal Democratic Republic of Ethiopia Ministry of Health; 2015.

17. The Ethiopian Public Health Institute. Key Indicators, Mini Demographic and Health Survey. Addis Ababa; 2019.

18. Organization WH. WHO Recommendations on Health Promotion Interventions for Maternal and Newborn Health 2015. World Health Organization; 2015.

19. Wilunda C, Quaglio G, Putoto G, et al. A qualitative study on barriers to utilisation of institutional delivery services in Moroto and Napak districts, Uganda: implications for programming. BMC Pregnancy Childbirth. 2014;14(1):259. doi:10.1186/1471-2393-14-259
20. Rishworth A, Dixon J, Luginaah I, Mkandawire P, Prince CT. "I was on the way to the hospital but delivered in the bush": maternal health in Ghana's Upper West Region in the context of a traditional birth attendants' ban. Soc Sci Med. 2016;148:8-17. doi:10.1016/j. socscimed.2015.11.018

21. Vermeiden T, Stekelenburg J. Commentary: maternity waiting homes as part of an integrated program for maternal and neonatal health improvements: women's lives are worth saving. J Midwifery Women's Health. 2017;62(2):151-154. doi:10.1111/jmwh.12618

22. Henry EG, Semrau K, Hamer DH, et al. The influence of quality maternity waiting homes on utilization of facilities for delivery in rural Zambia. Reprod Health. 2017;14(1):68. doi:10.1186/s12978017-0328-Z

23. Scott NA, Vian T, Kaiser JL, et al. Listening to the community: using formative research to strengthen maternity waiting homes in Zambia. PLoS One. 2018;13(3):3. doi:10.1371/journal.pone.0194535

24. Endalew GB, Gebretsadik LA, Gizaw AT. Intention to use maternity waiting home among pregnant women in Jimma District, Southwest Ethiopia. Global J Med Res. 2017:1:154.

25. Kurji J, Gebretsadik LA, Wordofa MA, et al. Factors associated with maternity waiting home use among women in Jimma Zone, Ethiopia: a multilevel cross-sectional analysis. BMJ Open. 2019;9(8):e028210. doi:10.1136/bmjopen-2018-028210

26. Sialubanje C, Massar K, van der Pijl MS, Kirch EM, Hamer DH, Ruiter RA. Improving access to skilled facility-based delivery services: women's beliefs on facilitators and barriers to the utilisation of maternity waiting homes in rural Zambia. Reprod Health. 2015;12 (1):61. doi:10.1186/s12978-015-0051-6

27. Abdulkadir RW. Awareness, Attitude Towards and Utilization of Maternity Waiting Home by Mothers in Merti Sub County, Isiolo County. COHES, JKUAT; 2017.

28. Spaans W, Van Roosmalen J. VAN WIECHEN CG. A maternity waiting home experience in Zimbabwe. Int $j$ Gynaecology Obstetrics. 1998;61 (2):179-180. doi:10.1016/S0020-7292(98)00027-7

29. Goshu M, Godefay H, Bihonegn F, et al. Assessing the competence of midwives to provide care during labor, childbirth and the immediate postpartum period-A cross sectional study in Tigray region, Ethiopia. PLoS One. 2018;13(10):e0206414. doi:10.1371/journal.pone.0206414

30. Vermeiden CJ. Safe Motherhood: Maternity Waiting Homes in Ethiopia to Improve Women's Access to Maternity Care. University of Groningen; 2019.

31. Gaym A, Pearson L, Soe K. Maternity waiting homes in Ethiopiathree decades experience. Ethiop Med J. 2012;50(3):209-219.

32. Bailey P, Lobis S, Maine D, Fortney JA. Monitoring Emergency Obstetric Care: A Handbook. World Health Organization; 2009.

33. Chandramohan D, Cutts F, Millard P. The effect of stay in a maternity waiting home on perinatal mortality in rural Zimbabwe. $J$ Trop Med Hyg. 1995;98(4):261.

34. Organization WH. World Health Statistics 2016: Monitoring Health for the SDGs Sustainable Development Goals. World Health Organization; 2016.

35. Shah P MDGs to SDGs: reproductive, Maternal, Newborn and Child Health in India. Observer Research Foundation ORF Occasional Paper. 2016;103:2-4.

36. Tiruneh GT, Taye BW, Karim AM, et al. Maternity waiting homes in Rural Health Centers of Ethiop: the situation, women's experiences and challenges. Ethiopian J Health Dev. 2016;30(1):19-28.

37. Ruiz IZ. Effectiveness Assessment of Maternity Waiting Homes in Increasing Coverage of Institutional Deliveries Using Geographical Information Systems in Six Districts of Cabo Delgado Province (Mozambique). 2010.

38. Vermeiden T, Braat F, Medhin G, Gaym A, van den Akker T, Stekelenburg J. Factors associated with intended use of a maternity waiting home in southern Ethiopia: a community-based cross-sectional study. BMC Pregnancy Childbirth. 2018;18(1):38. doi:10.1186/ s12884-018-1670-z 
39. Windsma M, Vermeiden T, Braat F, et al. Emergency obstetric care provision in Southern Ethiopia: a facility-based survey. BMJ Open. 2017;7(11):e018459. doi:10.1136/bmjopen-2017-018459

40. Kebede KM, Mihrete KM. Factors influencing women's access to the maternity waiting home in rural Southwest Ethiopia: a qualitative exploration. BMC Pregnancy Childbirth. 2020;20(1):1-12. doi:10.11 86/s12884-020-02988-8

41. Vermeiden T, Schiffer R, Langhorst J, et al. Facilitators for maternity waiting home utilisation at Attat Hospital: a mixed-methods study based on 45 years of experience. Tropical Med Int Health. 2018;23 (12):1332-1341. doi:10.1111/tmi.13158

42. Ruiz MJ, van Dijk MG, Berdichevsky K, Munguía A, Burks C, García SG. Barriers to the use of maternity waiting homes in indigenous regions of Guatemala: a study of users' and community members' perceptions. Cult Health Sex. 2013;15(2):205-218. doi:10.1080/13691058.2012.751128
43. Coast E, Jones E, Lattof SR, Portela A. Effectiveness of interventions to provide culturally appropriate maternity care in increasing uptake of skilled maternity care: a systematic review. Health Policy Plan. 2016;31(10):1479-1491. doi:10.1093/heapol/czw065

44. Birmeta K, Dibaba Y, Woldeyohannes D. Determinants of maternal health care utilization in Holeta town, central Ethiopia. BMC Health Serv Res. 2013;13(1):256. doi:10.1186/1472-6963-13-256

45. Mramba L, Nassir FA, Ondieki C, Kimanga D. Reasons for low utilization of a maternity waiting home in rural Kenya. Int $J$ Gynecol Obstetrics. 2010;108(2):152-153. doi:10.1016/j.ijgo.2009.08.029

\section{Publish your work in this journal}

The International Journal of Women's Health is an international, peerreviewed open-access journal publishing original research, reports, editorials, reviews and commentaries on all aspects of women's healthcare including gynecology, obstetrics, and breast cancer. The manuscript management system is completely online and includes a very quick and fair peer-review system, which is all easy to use. Visit http://www.dovepress.com/testimonials.php to read real quotes from published authors. 